\title{
Influence of pre and post-harvest technologies in effective yield, yield attributes and quality enhancement of medicinal and aromatic plants for healthy life
}

\author{
S. Tripathy Amrutanand*, H.V. Annegowda*, and Kuntal Das * \\ Dept. of Pharmacognosy and Phytochemistry, Krupanidhi College of Pharmacy, Carmelaram Post, Varthur Hobli, Bangalore-560035, KA, India \\ *Dept. of Pharmacognosy and Phytochemistry, Sri Adichunchanagiri College of Pharmacy, B.G. Nagara, Mandya-571 448, KA, India
}

\section{Article Info}

Article history

Received 12 January 2021

Revised 10 January 2021

Accepted 28 February 2021

Published online 30 June 2021

\section{Keywords}

Agricultural practices

Collection

Pre and post-harvesting

Drying

Storage

Medicinal plants

\begin{abstract}
It is affirm that a tremendous surge in wide acceptance and public interest in healthcare management with the natural herbals worldwide. The use of herbal medicines with its different forms continues to expand expeditiously along with the strong economic benefits across the globe. Despite their widespread versatile applications, the availability of the raw materials as well as finished herbal products is varied with the quality and hence, the variation observed in the quality. This disparity in the quality of herbal preparations is due to the complicated management of production with regard to the quality of basic raw plant materials. Again, the main sources of raw materials of plant species are from the forest zone of different climatic conditions. Therefore, domestication of the wild sources plant through proper systemic cultivation is essential. Good agricultural practise, processing, pre and post-harvesting practises have been highlighted in recent times as a significant tool for ensuring the protection and quality of medicinal and aromatic plants and their products for economic growth. The present article reviewed with the focus of various problems, developments strategies concern for the pre and post-harvesting technologies, drying techniques, storage of raw materials, and various modern extraction technologies of the medicinal and aromatic plant resources to provide sustainable quality herbal products with increase recovery of plant secondary metabolites.
\end{abstract}

\section{Introduction}

India is a diverse land with huge sources of flora and fauna which are being used in multidirections, especially as a source of health benefits as well as medicines for human beings and animals since time immemorial. According to the World Health Organization (WHO), it is analysed that over 80 per cent of the people in all countries embrace and rely on traditional medicine systems as impact on primary health management (Bodeker et al., 2005). In recent era, the demand for herbal medicines, various health products, pharmaceuticals, nutraceuticals, food supplements, cosmetics, perfumes. etc., are tremendously increased in the World market which is totally dependent on natural herbal plants. Hence, a huge percentage of medicinal and aromatic plants (MAP) are collected from natural habitats to fulfil the socio-economical demand. But, due to various man-made reasons, huge population, and overexploitation, many of the natural habitats are become rare, threatened, and endangered (Hamilton, 2008). The rapid genetic loss of MAP necessitates the need for conservation of the plant protection for availability to the future generations. Therefore, it is affirm that the medicinal plant conservation mainly based on the domestication through their cultivation in a scientific way especially

Corresponding author: Dr. Kuntal Das
Professor, Department of Pharmacognosy and Phytochemistry,
Krupanidhi College of Pharmacy, Carmelaram Post, Varthur Hobli,
Bangalore-560035, KA, India
E-mail: drkkdsd @ gmail.com
Tel.: +91-9632542846

Copyright $\odot 2021$ Ukaaz Publications. All rights reserved.

Email: ukaaz@yahoo.com; Website: www.ukaazpublications.com by Good Agricultural Practices (Foster, 1993). An effective way of the commercial cultivation of MAP provides an ample scope in enhancement of quality of the raw materials and quantity of the and by adopting improved pre and post-harvest practices, viz., site selection, use of quality planting materials, good agronomy practices, nutrient management, irrigation, integrated pest management, harvesting management, implementation of suitable post-harvest processing techniques and ultimate storage of the raw materials and finished products.

The yield, yield attributes and quality of MAP are greatly dependent on various internal and external factors, viz., authentication, the harvesting technologies, collection time and procedure, post-harvest practises such as drying, storage, packaging and processing (Pandey and Das, 2014). Therefore, identification of the various problems related to MAP production is the most important for further process. Maintenance of quality of the yield and the various yield attributes such as plant height, canopy size, number of branches, size of the fruits, flowers, etc., of MAP products is really a challengeable task. Thereafter, the quality of the final products is also deteriorating due to various reasons like, selection of wrong species, nonoptimum cultivation parameters, improper harvesting and collection time and seasons, inappropriate post-harvest methodologies, and finally storage conditions (Smitha, 2019).

\section{Factors influencing commercial cultivation of MAP}

The factors are, namely; pre-harvest factors, harvest management and post-harvest factors (Figure 1). 


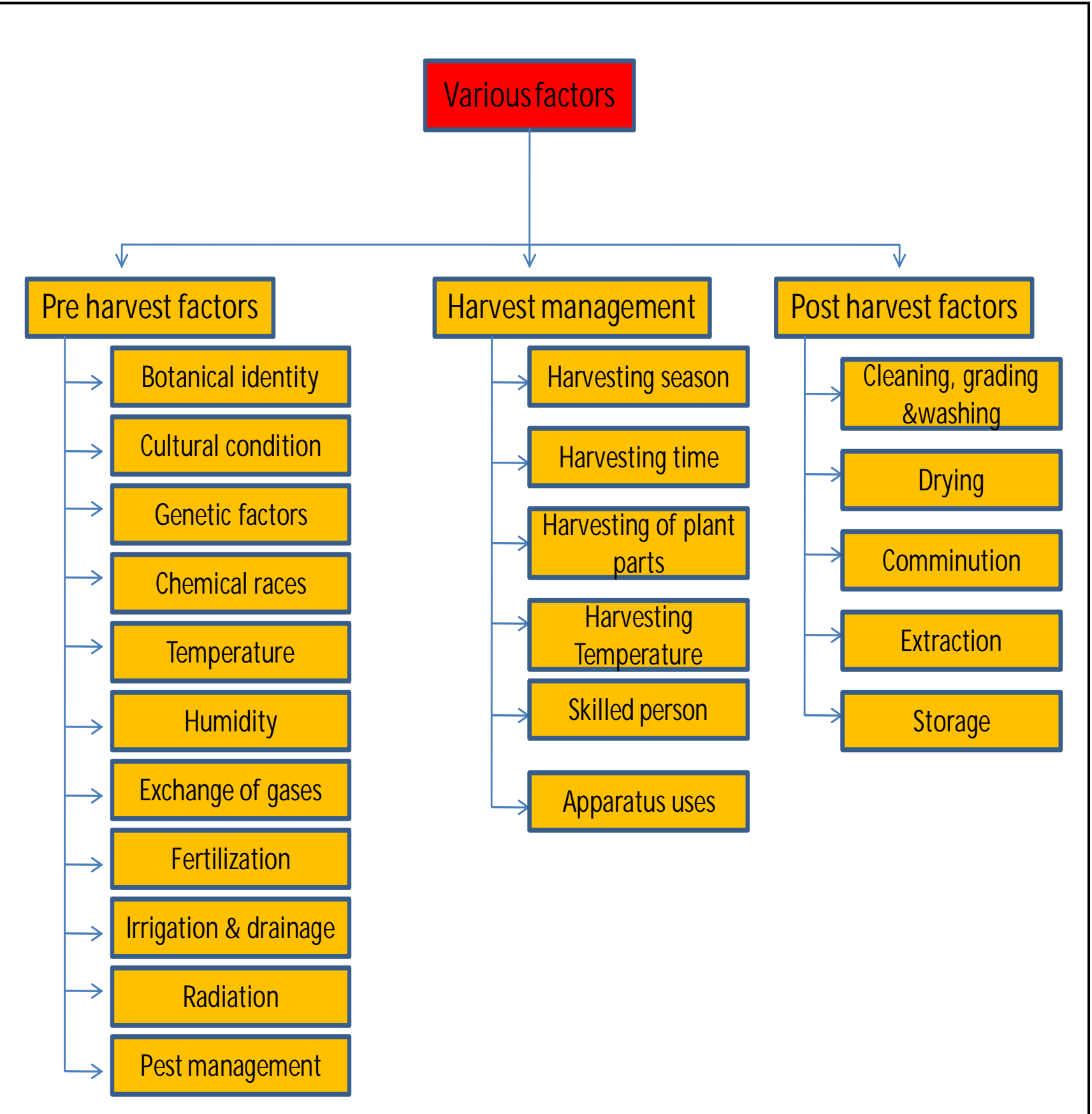

Figure 1: Various factors affecting commercial cultivation of MAPs.

\section{- Pre-harvest factors}

The yield and yield attributes of MAP are greatly dependent on pre-harvest factors such as botanical identity, cultural conditions and climates, soil health, seasonal variation, light intensity, temperature, irrigation, cultivar, soil fertility and nutrient management, cultural practice and pest and disease management.

\section{i. Botanical identity}

The most critical task and foremost important requirement for application of instinct, knowledge and skill is authentication or botanical identity. Botanical authentication means to afford communication about MAP to standardize and organize an unambiguous reference system about MAP.

An authentication of raw herbals follows mainly three steps namely; taxonomic identity, where the identification and authentication of herbal plants requires classical botanical methodologies for the selection and recording of the plant sources. The botanical origin of a herbal plant is established and its scientific Latin binomial name is determined on the basis of this procedure. Herbarium voucher study, in which the sample of collected material is to be deposited 
as a sample voucher in a herbarium or a research institution for future references and lastly, morphological and microscopic identities, where macroscopic identity of botanical materials is based on parameters such as form, scale, color, texture, surface characteristics, fracture characteristics, odor, taste. It is generally used to recognize and discern similarities between original and adulterated plant drugs (Das, 2020). Some examples are depicted in Table 1 .

Table 1: Botanical identity of various plant parts

\begin{tabular}{|l|l|l|}
\hline Indian name & Botanical name & Part uses \\
\hline Ashwagandha & Withania somnifera & Roots \\
\hline Guduchi & Tinospora cordifolia & Leaves \\
\hline Gudmar & Gymnema sylvestre & Leaves \\
\hline Guggulu & Commiphora mukul & Latex \\
\hline Brahmi & Centella asiatica & Leaves \\
\hline Bael & Aegle marmelos & Fruit \\
\hline Senna & Cassia angustifolia & Leaves \\
\hline
\end{tabular}

Many institutes and laboratories are involved in herbal drug authentication and among them, Central Council for Research in Ayurveda and Siddha (CCRAS), Central Council for Research in Yoga and Naturopathy (CCRYN). Homoeopathy Pharmacopoeia Laboratory (HPL), Indian Institute of Horticultural Research (IIHR), National Medicinal Plant Board (NMPB), Central Institute of Medicinal and Aromatic Plants (CIMAP), Regional Research Laboratory (RRL), Pharmacopoeial Laboratory for Indian Medicine (PLIM), National Institute of Ayurveda (NIA), National Institute of Siddha (NIS), are well known (Das, 2020).

\section{ii. Cultural conditions}

Geographical locations as well as climatic conditions are very serious issues for effective growth of the MAPs. As per Good Agronomic practice, the cultivation of the plants are adapted to a specific geographical location, and therefore, suitable location for the cultivation of such plants are of prime importance which are initially carried out by adaptability of the plants with their genetic factors and their chemical natures. Various factors like altitude, latitude, humidity, rainfall, light intensity, and many other parameters have an equal impact on healthy growth of MAPs. Examples: The carbohydrate content in leaves is reduced in cloudy weather due to rate of photosynthesis is decreased and also the amount of secondary metabolites is dependent on presence of the carbohydrate. The effect of latitude in fat producing plants is significant. Tropical plants (palm oil, cocoa butter) contain mainly saturated fatty acids, while the subtropical plants produce more unsaturated acids (Chin et al., 2020). The olive, almond and sesame oils are predominant in oleic acid. The plants of temperate zones (cottonseed, sunflower) also contain more unsaturated acids. Peanut and olive trees grown in the subtropics, have a higher unsaturated fat content. Cinchona succirubra is seen to grow well at low levels, but alkaloids are not formed. May be the alkaloid content of Aconitum napellus and Lobelia inflata, and the oil content of Thyme and Peppermint can decrease at altitude, while the bitter constituents of Gentiana lutea are increased with altitude (Niiho et al., 2006). Pyrethrum yields flower-heads and pyrethrins at high altitudes in Equator (East Africa) (Haile, 2017).

\section{iii. Genetic factors}

Morphological differences and biochemical variations are dependent on genetic differences. Information on genetic divergence is essential for sustained genetic improvement of a crop. Genetic markers are used for the improvement of the crop production. They represent genetic differences between individual organisms or species. Molecular markers are being increasingly used for divergence studies and are known as genotypic markers. They may not influence the phenotype of the trait of interest since they are located close or related to genes regulating the trait. Both genetic markers have unique genomic locations within chromosomes that are known as loci. It is used for characterization and identification of cultivars, varieties and natural populations as well as used to understand the genetic variability of population (Das, 2018). They are of three classes, namely; morphological markers, which themselves are phenotypic traits or characters, biochemical markers, which include allelic variants of enzymes called isozymes and DNA markers, which reveal sites of variation in DNA which are identified by RFLP (Restriction Fragment Length Polymorphism) and Random Amplified Polymorphic DNA for polymerease chain reaction (Liu and Cordes, 2004).

\section{iv. Chemical races}

It is also known as chemodemes. They are regarded as a group of plants with similar morphological characters, but differing in chemical composition. Hence, chemodemes are considered as chemically separate groups within species. The chemical characters of chemodemes are hereditary. Genotype and phenotype are together responsible for chemical races. Genotype refers to the genetic traits in an organism. Present genotyping methods include RAPD, and RFLP of genomic DNA, amplified fragment length polymorphism detection (AFLPD), polymerase chain reaction, DNA sequencing, allele specific oligonucleotide probes, and hybridization to DNA microarrays. Phenotype refers to observable, physical manifestations of an organism. Some examples are like, Withania somnifera has three chemical races, Chemotype I and II contains same compounds withaferin, and chemotype III contain withanolides, where both these active constituents have different medicinal action (Manan et al., 2020). Chemical races have also been reported in Claviceps purpurea, Digitalis purpurea, Digitalis lanata, Cinnamomum zeylanicum, Ocimum sanctumetc (Das, 2018).

\section{v. Temperature}

Plant growth depends on the fluctuation of temperature by affecting the rate of chemical reactions. Excessive temperature as well as frost also affects the growth, quality and metabolism of the medicinal plants. High temperature leads to death of the plants, and low temperature infects the plants by microorganisms. Alkaloids content become lower in Datura stramonium during cloudy/rainy weather, warmer weather is favourable for production of volatile oil, but very hot days lead to a physical loss of oil; peppermint grows more in shade rather than in sun light. In rainy and cloudy weather, Stramonium leaves shows less accumulation of alkaloids (Das, 2018). For seed germination temperature should be $15-20^{\circ} \mathrm{C}$. Optimum 
temperature for propagation is $18-28^{\circ} \mathrm{C}$ in which day temperature should be $21-27^{\circ} \mathrm{C}$ and night temperature $15^{\circ} \mathrm{C}$.

\section{vi. Humidity}

Humidity is typically expressed as a proportion of the maximum amount of water vapour that the air retains at specific temperatures. Based on that, absolute, relative and specific humidity are used to measure the humidity (Das, 2018). Measurement of moisture content in air is done by absolute humidity, whereas the ratio of real moisture content to the saturated moisture content at particular pressure and temperature and pressure is known as relative humidity which is expressed as percentage. Furthermore, specific humidity is a mass of moisture in a unit mass of the total air. It is expressed as $\mathrm{g}$ of moisture $/ \mathrm{kg}$ of total air. Hence, humidity plays a significant role in performance and final yield of the plants grown in shades. Examples: Optimum humidity for plant growth is $50-80$ per cent; high humidity encourages the spread of fungal diseases, whereas low humidity increases transpiration. Generally humidity is measures using a psychrometer or hygrometer. Relative humidity directly affects plant water relationships and indirectly impacts leaf growth, photosynthesis, pollination, diseases and ultimately yield (Mortensen, 2000). An atmosphere dryness is expressed by saturation deficit (100-RH) reduces the output of dry matter through water potential of leaf and with stomatal control.

\section{vii. Exchange of gases}

The supply of carbon dioxide is most important gas in order to carry out the photosynthesis by the green plants and to release of oxygen. Plants need more oxygen for cellular respiration and releases carbon dioxide. Therefore, large volume of gaseous exchange is taken place during photosynthesis through the leaves (stomata) mostly and passes through the cell wall and plasma membrane with the diffusion mechanism. High respiration rate occurs with seed germination and during advantageous root formation at the base of cuttings, so it requires more oxygen and removal of $\mathrm{CO}_{2}$. Gas exchange occurs through the moist epidermal layers of the young roots. On other hand, gaseous exchange in lower plants is taken place through the general body surface. Also, the body surface allows the diffusion of gases (Das, 2018). In the same manner, soil helps to introduce oxygen into the cells through diffusion while carbon dioxide diffuses out from the plant cells.

\section{viii. Fertilization}

The dosage of the fertilizers is based on the growing media. It is evident that the mixture without soil is having lower nutrient holding capacity and, hence requires more fertilizer application frequently. The $\mathrm{pH}$ ranges of 5.5 to 6.5 shows rich sources of essential elements. At low $\mathrm{pH}$, microelements are more readily available but at $\mathrm{pH}$ higher than 6 shows the higher presence of macroelements in soil (Neina, 2019). Recently, nanofertilizers are demanded for improvement of the crop yield. Nanofertilizers are the fertilizers that contain nanoparticles with higher nutrient efficiency which continuously and directly supply essential nutrients to the plants for their healthy growth. They are applied on time in soil or by foliar spray. Such as, Slow release nano nitrogen fertilizer: Nano zeolite when soaked with urea, causes slow and steady release of $\mathrm{N}$ due to $\mathrm{NH}^{+}$ions entrapping in the internal channel soft zeolites that slowly releases nitrogen and allowing progressive absorption by the medicinal plants. Slow release nano phosphate fertilizer:
Surface modified zeolite is a well sorbent for $\mathrm{PO}^{-3}$ that releases monophosphate slowly in soil (Guo et al., 2018). Uptake of nano micronutrients: It is revealed that application of zinc nanoparticles $(<100 \mathrm{~nm})$ at $0.28 \mathrm{ppm}$ dose enhanced the growth of maize plant as compared to normal zinc sulphate $(0.5 \mathrm{ppm})$. The plant height, root growth and volume, dry matter weight can also improve with application of zinc oxide nanoparticles (Das, 2018).

\section{ix. Irrigation and drainage}

Based on the requirement of the individual medicinal plant, irrigation and drainage system needs be controlled during various growth stages of the plants. Irrigation is carried out using quality water that should comply with local, regional and national quality standards. Irrigation should be carried out to ensure the plants under cultivation are neither over- nor under logged watered. First light irrigation is required during land preparation and initial sowing of the seeds. It gives fast germination rate to get plantlets.

\section{x. Radiation}

Plant growth and healthy raw materials are mostly affected by the solar radiation. The most important physiological parameters of the plants such as seed germination, leaf expansion, growth of stem and shoot, flowering, fruiting are requires solar light. Not only that, solar radiation also influences assimilation of nutrient and dry matter distribution in the plants. The most essential function, photosynthesis, the growth rate of plants and many other environmental parameters are possible only with solar radiation. In solar radiation, visible light is a photosynthetically active radiation and its wavelengths lies between 400 to $700 \mathrm{~nm}$ which utilized by the plant biochemical processes to convert into biomass yield. Light energy can also be defined in radio metric units, which is measured with a pyranometer. Solar radiation is used to determine the total energy value (radiometric units, $\mathrm{Wm}^{-2}$ ), or the amount of the sunlight that uses for plant growth in a specific growth period $\left(\mathrm{molm}^{-2}\right.$ or in quantum terms $\mathrm{mmols}^{-1} \mathrm{~m}^{-2}$ ). Radiation energy has three components, (a) quality (b) intensity and (c) duration of light. They influence the physiological process of the plants for the healthy growth such as the quality in terms of wavelength and colour, quantity in terms of the intensity and light exposure time, etc. (MousaviMaleki et al., 2017). Quantity of light is calculated as $\mathrm{cal} / \mathrm{m}^{2} / \mathrm{year}$ which are known as Lux (luminous flux per unit area, $\left.1 \mathrm{~L} / \mathrm{m}^{2}\right)$. The intensity of light has much effect on the uptake of phosphorus and potassium. Oxygen intake increases with the increase of light intensity. Some species of plant produce more active constituents at night like Nicotiana tobacum whereas phenol and terpenoids contents in the leaves of Ocimum basilicum are decreased when grown in glass houses. On the basis of reaction to the photoperiod, the plants are classified as short, long and intermediate day plants. Short day plant: Tobacco, menthofuran; long day: grains, menthone, menthol; intermediate day: cotton (Das, 2018).

\section{xi. Pest management}

Reduction in the quantity of the crude drugs also depends on the pests and their attack. The huge losses due to pest infestation tune to lakhs of rupees every year due to less medicinal values. Pests are detrimental for the plants and, thus controlling them during cultivation of medicinal plants is essential. These pests include fungi, viruses, weeds, insects and rodents (non insect pests). Some 
fungal pests are like Pythium spinosum (rhizomerot), Currularia prasadii (leaf blight), Septoria digitalis (leaf spot), Cercospora rauwolfiae (leaf spot), etc. Fungus on henbane lowers the alkaloid content. Some of the viruses like TMV (Tobacco Mosaic Virus), CMV (Cucumber Mosaic Virus) and TRS (Tobacco Ring Spot) viruses attack the digitalis plant. Several insects can also cause problem in the growth of the plants, e.g., Diaphania nilagirica attack Rauwolfia plant, Phytomyza atricornis attack Mentha plants, etc. (Das, 2018). Weeds are also considered as dreadful pests that are undesired plants. They can resist the growth of the original plants. Some weeds also caused allergies, e.g., hay fever caused by rag weed, asthma cause by parthenium, etc. Non-insect pests like rats, monkeys, birds, snails, mites, crabs also spoil the stored crude drugs.

There are some methods available to control the pests:

Mechanical method: During preliminary stages, they can be controlled by hand picking, pruning, burning and trapping.

Agricultural method: Advanced breeding techniques are capable of gene manipulation in different stages of the plant growth to get disease free healthy plants. These methods include hybridization, polyploidy, mutation and chemical races. To control weeds, ploughing should be deep as possible so that up-rooting of the weeds is possible. Crop rotation also helps to minimize the attack of the pests.

Biological control: This is very useful method by combating the pests with other living organisms. Example, the chemical substances produced (7,8-epoxy-2-methyl octadecane) and released by gypsy moth are capable to elicit sexual response from the opposite sex and that can control the pests. Mexican brittles controls the parthenium by sucking the root sap of parthenium weeds; Australian lady bug feeds on damaging insect called cottony cushion scale insect on citrus crop, etc.

Chemical control: The use of chemical pesticides also helps to control the pests like insecticides, fungicides, herbicides and rodenticides. Only authentic and certified pesticides and herbicides are applied at the minimum effective level for the significant action and for the healthy growth of the plants. Some examples are:

Rodenticides: Warfarin, strychnine red squill, etc.

Insecticides : DDT, parathion, gammaxine, etc.

Fungicides : Bordeaux mixture, chlorophenols, etc.

Herbicides : 2,4-dichloro phenoxy acetic acid, calcium arsenate etc.

Many commercial pesticides are discovered by the laboratory for pesticidal properties, but maximum halogenated hydrocarbon products are commercialized as important pesticides. They have long environmental half-lives and more toxicological properties. Since the 1960's, by the use of synthetic pesticides, the pest management are carried out in the industrialized developed countries, but biopesticides have some advantages over the synthetic pesticides that (a) these are easily biodegradable and no harmful residue is left on the treated surface, (b) they are target specific and not harmful to the natural enemies, (c) very small amount biopesticides are effective and often quickly decompose biofriendly and also no pollution problem as like chemical pesticides, (d) in
Integrated Pest Management (IPM) programs, biopesticides are used as a component which do not affects the crop yields. Hence, biopesticides are in demand in discovery of pesticides. Biopesticide means "bios", i.e., living and "pesticide", i.e., the material causing alternation of normal important functions of an organism by reducing their birth or by death. So, biopesticide is the pesticide that derived from natural sources (like animals, plants, minerals and microorganisms) and controls the pests by non-toxic mechanisms (Khader Khan, 1996). Examples like:

\section{Animals that act as biopesticides}

1. Brachonids, Chalcids (Insects), they can destroy leaf eating caterpillars.

2. Ladybugs, they consume aphids, mites and white flies.

Plants that act as biopesticides

1. Neem

2. Tobacco

3. Pyrethrum

4. Hemp

5. Canolaoil

6. Citronellaoil, etc

Minerals that act as biopesticides

1. Baking soda

Microorganisms that act as biopesticides

1. Entomopathogenic fungi are like Beauveria bassiana, Lecanicillium lecanii, etc.

2. Plant disease control agents are like Trichoderma harzianum and Ampelomyces quisqualis, Bacillus subtilis, etc.

3. Nematodes are like Steinernema feltiae

4. Entomopathogenic viruses are like Cydiapomonella granulovirus.

5. Bacterial insecticides are like B.t. kurstaki, B.t. aizwai, B.t. tenebrionis, etc.

On an average, consumption of biopesticides is around $1.5 \mathrm{~kg} / \mathrm{ha}$ globally which is growing very rapidly in market. Spores of the bacteria such as Bacillus thuringiensis (Bt) is widely used biopesticide which is first ever biopesticide discovered by Shigetane Ishiwata in 1901 (isolated from a diseased silkworm) (Chandler $e t$ al., 2011). Further, Ernst Berliner in Thuringen, Germany, rediscovered $\mathrm{Bt}$ bacteria in a flour moth after 10 years of previous discovery and then classified as type species Bacillus thuringiensis in 1911 and then started to use B t as a bioinsecticide from early 1920's. In France (1938), the first commercially available Bt product is Sporeine. Further, Agrobacterium radiobacter containing commercial products are used in prevention of crown gall diseases on woody crops and Pseudomonas fluorescens are used for the mitigation of fire blight in orchards in place of streptomycin since from 1990's. In 2005, the used of biopesticides are increased about $2.5 \%$ from the $0.2 \%$ during 2000 of the total pesticide market. In 2006, Arysta Life Science estimated the worldwide biopesticide market at approximately $\$ 541$ million whereas Global Industry Analysts, Inc.(GIA) estimated about 3 per cent (\$750 million) of total pesticides in year 2008 and reached about $\$ 1$ billion mark by 
2010. This share grown about 8.2 per cent in 2015 but it is estimated that the application of biopesticides expected to shoots up about 14 per cent per annum in 2020 . Orchards claim the maximum 55 per cent share of the total biopesticides that uses in the market where North America itself consumes 42 per cent of the total biopesticide produced globally followed by Europe and Oceanic countries (Das, 2018).

\section{- Integrated pest management (IPM)}

It is an ecofriendly, effective approach to economically control the pest by knowing the information on the pest's life cycles with their activities. It is based on the combination of preventive measures that controls the development of detrimental pest populations and lowers the risks to human health and the environment. Alternately, the system helps in healthy growth of the crops without affected agro-ecosystems (Das, 2020; Dara, 2016). It is based on some principles such as:

\section{Step 1: Acceptable level of the pests}

This is the first and primary focus of the IPM programmes where action thresholds are established to know acceptable level of pests. Further based on limit of action thresholds for pest as well as site specific, the control methodology is applied. The selection pressure is reduced based on pest population that survive at a basic threshold level.

\section{Step 2: Cultural practices prevention}

It indicates removal of diseases plants which is known as first line defense of plants as well as crop sanitation.

\section{Step 3: Monitoring}

Daily observation is the prime work of IPM. During observation time, various tools and specific measurement methods along with visual inspection are adopted to monitor the pest levels and further recorded in a book for accurate pest identification.

\section{Step 4: Mechanical control}

This method is carried out when the pest attack first to the plants. The method uses like simple hand-picking, erecting insect barriers, tillage to disrupt breeding, using traps, vacuuming, etc.

\section{Step 5: Biological control}

It indicates like kills like, i.e., killing of target pests by using beneficial pests such as Bt. Entomopathogenic fungi and entomopathogenic nematodes, and also Mexican brittles (controls parthenium).

\section{Step 6: Responsible pesticide use}

Recently, many plants or naturally occurring substances are used as pesticides such as nicotine, pyrethrum, neem, etc., to avoid the health hazards, caused by the synthetic pesticides.

\section{Soil health}

i. Soil texture: The physical characteristics of the soil are assessed qualitatively using soil texture. It can be determined by proportion of soil through and, clay, slit and water holding capacity of the soil. It is used to determine crop suitability and responses to environmental and management conditions. It has an important role in nutrient management and has greater ability to store soil nutrients. Thereafter, flowing of water, holding capacity of water, soil fertility, etc., is also revealed with the soil texture. ii. Soil structure: Soil structure is the grouping of the soil particles (such as sand, clay, organic matters, etc.) in the form of aggregates or soil tilth. It is an arrangement in the form of distinctive shapes that located in soil horizons. It is seen that surface horizon contains generally granular oil particles. Soil aggregation plays a significant role in soil.

iii. Soil profile: The most important parameter is a soil that helps in nutrient management by knowing the actual natural soil fertility. The most important aspect is that the soil profile changes with the weather conditions and the decomposition of the organic matters into the soil. The soil profile is varied in thickness as well as depends on the location and, hence divided into distinct horizons with irregular boundaries (Figure 2) (Das, 2015).

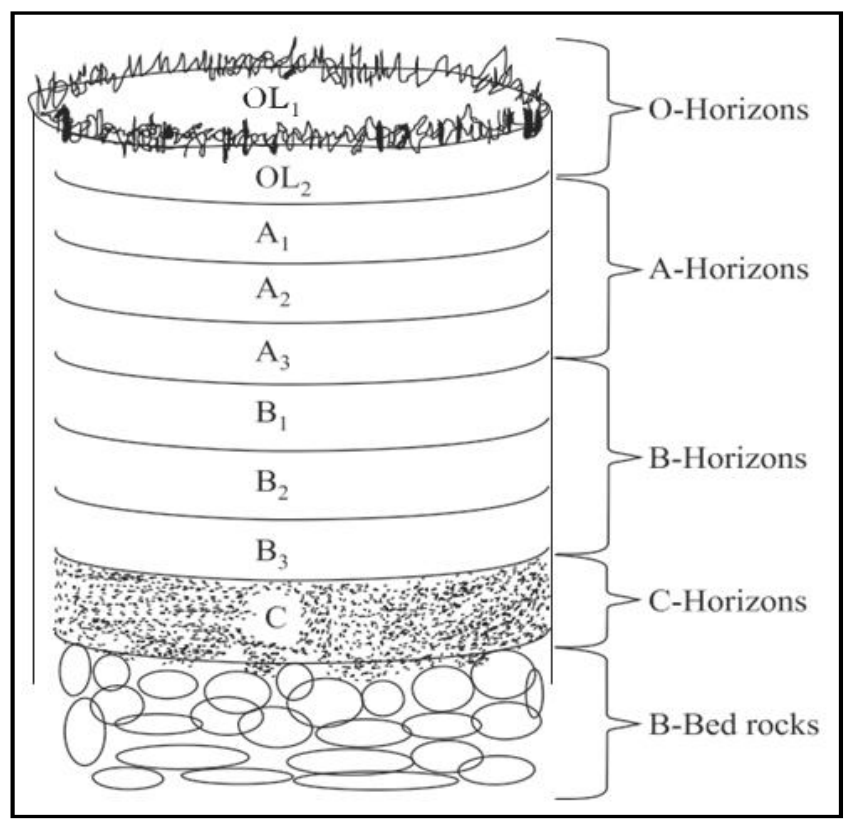

Figure 2: Soil profile (Source: Das, DK, Introductory Soil Science, 2015).

O horizon: It is an upper surface layer with the presence of huge decomposed organic material and, hence the layer is known as organic layer or $\mathrm{O}$ horizon. The layer do not contains any weathered mineral particles and hence, the layer is not considered as a part of the soil. It contains high percentage of dead organic matter. This horizon is divided into $\mathrm{OL}_{1}$ and $\mathrm{OL}_{2}$ where $\mathrm{OL}_{1}$ contains decomposed matter (on the surface of the soil) and $\mathrm{OL}_{2}$ contains well decomposed organic matters.

A horizon: The layer is alternately known as top soil because this A horizon is situated in the actual to player of the soil with rich content of humus or dark decomposed organic materials. The layer is more suitable for plant growth because it contains more organic material but contains minimum quantities of clay or sesquioxides. This layer is subdivided into $A_{1} A_{2}$ and $A_{3}$. $A_{2}$ layer is known as washing out of clay. $\mathrm{A}_{3}$ layer is intermediate layer between $\mathrm{A}$ and $\mathrm{B}$. In this horizon, maximum biological activities are taken place with the presence of beneficial biotic organisms, viz., earth worms, pot worms (enchytraeids), arthropods, nematodes, fungi, many species of bacteria, archaea, etc., and hence the layer is also known as the biomantle. They help in growth of the plant roots. 
B horizon: The layer contains rich of minerals like iron, aluminium oxides and leaching of organic layer and hence, the humus is less. Therefore, the layer is known as "subsoil" or "illuviated" horizon or the "zone of accumulation". The soil of this layer is generally brownish or red due to rich content of iron oxide but the roots of the plants are penetrated through this layer and moves towards the next layer. This layer is also divided into three sub layers, viz., $\mathrm{B}_{1}, \mathrm{~B}_{2}$ and $\mathrm{B}_{3}$.

C horizon: The layer is the last but one layer of the soil profile which comes after A and B layers. The layer is not having much effect by soil weathering and the lack of pedological development. The layer contains lumps or large shelves of unweathered rock as like Ghost rock" which provide the frame work of the soil. The layer helps to form A and B layers.

Bed rocks: The layer is the structural layer of the soil profile which situated utmost down. The layer comprises continuous masses of the hard rock and partially weathered at the base of the soil profile. In situ soils formed from this bed rocks.

iv. Soil types: Soil is made up of the different sizes of mineral particles along with finely ground rock particles. They are grouped according to size of the particles such as clay, loam, clay-loam, silt-loam and also clay, humus, decomposed organic materials, etc. The sand particle helps in aeration and drainage of water whereas clay particles are chemically active which has water holding capacity and plant nutrients.

The types of Indian soil (Das, 2015)

Alluvial soils: The types of soils are most important soil group and essential for agricultural wealth. These soils included ltaic alluvium, calcareous alluvial soils, coastal alluvium and coastal sands which are derived from the deposition of the Indus, Ganges and the Brahmputra.

Black soils: These soils are also known as black cotton soil, derived from Deccan trap which distributed from shallow to deep. This type of soil is abundantly located in Kerala, Maharashtra, Western parts of Madhya Pradesh, A.P., Gujarat, and Tamil Nadu.

Red soils: The soils are formed by the meteoric weathering of ancient crystalline and metamorphic rocks. The red color is formed by the wide diffusion of iron metals. The red soils are located in various states of India such as Tamil Nadu, Karnataka, Goa, Daman and Diu, M.P., Orissa, Jharkhand, Bihar, West Bengal and U.P.

Desert soils: The most predominant component of this soil is quartz and contains high percentage of soluble salts and its $\mathrm{pH}$ is very high due to presence of high percentage of calcium carbonate. Hence, the soil contents very poor inorganic matter.

Problem soils: By the name of the soil, it well understood that the soil is waste soil and cannot be economically used for the cultivation of crops until proper reclamation. These soils are owing to land and soil characteristics.

Laterite soil: The soil is composed with the mixture of hydrated aluminium and iron oxides with small amount of manganese metals. This soil is poor in lime, magnesia, and nitrogen but high in humus, $\mathrm{P}_{2} \mathrm{O}_{5}$.

Acid soils: It is well understood that the soils having pH below7. Some soils are having $\mathrm{pH}$ less than 5.5 which are not useful for any crop cultivation, so those soils $\mathrm{pH}$ can improved by liming and makes useful. These occur widely in Himalayan region, Genetic delta and Peninsula. v. Soil aeration: The exchange of oxygen and carbon dioxide between soil pore and the atmosphere is the soil aeration. It is required to prevent the deficiency of oxygen and toxicity of carbon dioxide. It is the respiration by the roots of the plants and microorganisms depletes oxygen with the release of carbon dioxide and with some other gases in soil (Gougoulias et al., 2014), but the content of these toxic gases varies with temperature, organic matter and microbial respiration. Therefore, continuous oxygen flow in soil and outflow of carbon dioxide is essential for the healthy growth of the plants. Looses oil facilitates exchange of gases very easily between the soil air and atmosphere but the pores of the air is varied from 15 to 30 per cent of the total volume that depends on the water content, soil density and structure of the soil (Easton, 2016).

vi. Soil fertility: The fertility of soil involves the constant cycling of organic and inorganic nutrients in the soil. The method is complex where the plant material and animal wastes decompose and release nutrients naturally in the soil. Thereafter, undergoes transformations by soil microorganisms and capable of fixing atmospheric nitrogen by converted to $\mathrm{NO}_{2}$. Further, Denitrification occurs under an aerobic conditions in the presence of denitrifying bacteria which increases the soil fertility at higher level. Not only that, the cation exchange capacity also helps in procuring the right fertilizers to get the highest possible crop productivity. They are cations of phosphate and potash, as well as of many micronutrients which are held with strong bonds with the negatively charged portions of the soil (Das, 2015).

vii. Soil temperature: Many chemical reactions and biological interactions in soil is takes place due to the soil temperature which varies in response to exchange processes. The variation occurs primarily in the soil surface and thereafter distributed into the soil profile by transport processes. Such temperature variations are influenced by the specific heat capacity, thermal conductivity and thermal diffusivity (Das, 2015). A denser and less reflective material increases the soil temperature by inhibiting evaporation. Seed germination greatly dependent on soil temperature such as in cold condition the germination rate is delayed and resulted in seed damage and uneven or inadequate seeding emergence. Soil temperature is measured with the thermometer which placed at a specific depth but is dependent on various factors such as:

- Solar radiation: Soil temperature greatly dependent on the amount of heat in terms of sun light reaches in the earth. Generally with the normal value of $2.0 \mathrm{cal} / \mathrm{cm}^{2} \mathrm{~min}^{1}$ radiation received by the soil and the same depends on angles with which the soil faces the Sun.

- Condensation: The heat increases the moisture content in terms of water vapour from soil depths or atmosphere by the process of condensation method of the soil.

- Evaporation: The soil temperature affected by the rate of evaporation where higher the evaporation rate soil becomes cool very fast.

- Rainfall: Rainfall cools the soil environment. 
- Colour of the soil: Black colored soils absorb more heat than light closured soils and hence, those soils are warmer than other soils.

- Moisture content: The soil with higher moisture content is much cooler than dry soil.

- Tillage: Tillage helps in maintaining soil temperature and hence the cultivated soil has greater temperature amplitude than the uncultivated soil.

- Soil texture: Thermal conductivity of the soil decreases with decreased in soil particle size.

- Organic matter content: Organic matter reduces the heat capacity and thermal conductivity of soil. They increase also water holding capacity and increases heat absorbability due to its black texture.

viii. Soil pH: The soil $\mathrm{pH}$ meter is used to measure the acidic or basic nature of the soil. $\mathrm{pH}$ is the negative logarithm (base10) of the hydronium ion concentrations $\left(\mathrm{H}^{+}\right.$or $\left.\mathrm{H}_{3} \mathrm{O}^{+} \mathrm{aq}\right)$ in a solution. It has a scale of $0-14$ where $7^{\text {th }}$ point is considered as neutral. $\mathrm{pH}$ less than 7 is considered as acidic nature and above 7 to 14 is considered as basic nature. Highly acidic soil is converted near neutral by using lime solution. Soil $\mathrm{pH}$ is always varies but controls various chemical processes in soil for the proper availability of the plant nutrient (Das, 2015). The optimum $\mathrm{pH}$ ranges from 6 to 7.5 for healthy growth of the medicinal plants. Manganese (Mn) plays a significant role as plant nutrient that transported into leaves but manganese toxicity observed at $\mathrm{pH}$ below 5.6. It is observed that slight alkaline soil ( $\mathrm{pH}$ at 7 to 7.5 ) increases the availability of molybdenum and macronutrient but in the same soil nature, $\mathrm{P}, \mathrm{Fe}, \mathrm{Mn}, \mathrm{Zn}$, $\mathrm{Cu}$, and Co levels are decreases which adversely affect plant growth. In other hand, micronutrient availability (except for molybdenum (Mo) and boron (Bo)) is increases in acidic soil. It is also observed that concentration of nitrogen is less sensitive to $\mathrm{pH}$ than the concentration of available phosphorus (Neina, 2019). Soil pH in the range of 6.0 to 7.5 is optimum for the availability of phosphorus. If, the $\mathrm{pH}$ is less than 6 , phosphorus forms complex compounds with iron $(\mathrm{Fe})$ and aluminium (Al) which is insoluble in nature and thereafter, if the $\mathrm{pH}$ is higher than 7.5, the same phosphorus form insoluble complex with calcium $(\mathrm{Ca})$. In $\mathrm{pH}$ ranges between 5.5 to 6.5 , nutrient deficiencies are less and, therefore, determination of soil $\mathrm{pH}$ is most essential in nutrition management (Das, 2015).

ix. Beneficial soil microorganisms: The interrelationship between plant and soil is maintained by several beneficial soil microorganisms. These organisms are located in the root zone area in the soil (rhizosphere) and trigger the growth of plants with various mechanisms. Microorganisms such as fungi and bacteria present in soils are helpful in fast growth of the higher plants with the mechanisms of (a) direct acing with root zones (mycorrhizae, nodule forming bacteria); (b) release of minerals from organic matter acts as essential requirement for the plants; (c) disease causing microorganisms; (d) chemical inhibition process is for the mitigation of harmful disease causing microorganisms, suppressing growth, reproduction etc. The beneficial organism helps in uptake of water, soil nutrition and also helps in fixation of atmospheric nitrogen in the root zone for increasing plant growth. Furthermore, beneficial microorganism such as photosynthetic bacteria (Rhodopseudomonas sp), lactic acid bacteria (Lactobacillus sp.), yeast (Saccharomyces sp.) and fermenting fungi are also improving the soil fertility for healthy growth of the plant biomass (Naik et al., 2020).

Beneficial organisms: Insects: Beneficial predators (such as lady bugs) of pest insects and pollinators (such as bees) are helping in growth of many plants. Furthermore, certain beneficial species of insects are helping for natural pollination. Small beneficial insects such as Brachonids, Chalcids and Ichneumon. Wasps are culturing to destroy leafeating caterpillars.

Nematodes: Some microscopical worms are beneficial in destroying and controlling populations of leaf eater larvae. Furthermore, some useful ecofriendly products are applied to kill various kinds of harmful larvae (fungusgnats, flealarvae, spidermites, weevils, grubs, rootworms, cut worms, etc., (Das, 2018).

x. Nutrient management: Nutrient is an essential for the healthy plant growth. There are various natural sources of plant nutrients such as plant debris, green manure, compost, waste manure as well as artificial chemical fertilizers. Perhaps, in all fertilizers have their adverse effects and benefits also. These fertilizers plays a major role in increasing crop biomass production, therefore, balanced fertilization is to be considered for effective cultivation. The main two types of nutrients such as macro and micronutrients are most affects the plant growth. The role of macronutrients such as sodium $(\mathrm{N})$, potassium $(\mathrm{K})$, phosphorus $(\mathrm{P})$, sulphur $(\mathrm{S})$, calcium $(\mathrm{Ca})$, magnesium $(\mathrm{Mg})$ and micronutrients such as iron $(\mathrm{Fe})$, manganese $(\mathrm{Mn})$, boron $(\mathrm{B})$, copper $(\mathrm{Cu})$, zinc $(\mathrm{Zn})$, molybdenum (Mo), nickel (Ni) are can not be ignored. Although, plants need micronutrients in small quantities, but are most essential in healthy growth. But, the quantities of these nutrients in plants are varied with multiple factors such as types of plants, variety, climatic condition, soil nature and application of fertilizers. Therefore, recently Integrated Plant Nutrient Management system plays a major role in sustained healthy cultivation of MAPs which optimizes the soil condition based on physical, chemical, biological and hydrological natures. This results the enhancement of healthy biomass production with very less land degradation (Gareau, 2004). Some important examples are like, application of $\mathrm{N}$ fertilizer improves the alkaloid content of Rauvolfia and Atropa; Diosgenin content in Dioscorea and Costus; sennosides content in Cassia and essential oils content in Cymbopogon, Vetiveria and Mentha species. By increasing nutrients, biomass as well as accumulation of active principle varies like in kalmegh the active principle accumulation remains unchanged while in Costusthe active principle content decreases (Chatterjee, 2002). In Ocimum basilicum, application of $\mathrm{N}$ increased concentration of methyl chavicol and decreased linalool content (Prakasa Rao et al., 2007). Deficiencies of $\mathrm{P}$ and $\mathrm{K}$ resulted in variations in essential oil 
content and composition in some aromatic plants grown in red soils (Prakasa Rao et al., 1996). Biofertilizers are also plays an important role for nutrient uptake and supply of soil nutrient to the plants for the effective growth (Sneha $e t$ al., 2018). Some biofertilizers such as Rhizobium, Cyanobacteria, Azatobacter, Mycorrhizae (Vesicular Arbuscular Mycorrhiza) are helpful in atmospheric nitrogen fixation in soil and enhance the soil fertility (Barman et al., 2017) (Table 2).

Table 2: Various types of biofertilizers that applied in the plant growth

\begin{tabular}{|c|c|c|}
\hline Category & Group & Examples \\
\hline \multirow{3}{*}{$\begin{array}{l}\text { Nitrogen fixing } \\
\text { Biofertilizers }\end{array}$} & Free-living & Azotobacter, Clostridium, Anabaena, Nostoc \\
\hline & Symbiotic & Rhizobium, Frankia, Anabaena azollae \\
\hline & Associative Symbiotic & Azospirillum \\
\hline \multirow{3}{*}{$\begin{array}{l}\text { Phosphorus } \\
\text { Solubilizing } \\
\text { Biofertilizers }\end{array}$} & Bacteria & Bacillus megaterium var. phosphaticum, Bacillus circulans, \\
\hline & & Pseudomonas striata \\
\hline & Fungi & Penicillium sp., Aspergillusawamori \\
\hline \multirow{3}{*}{$\begin{array}{l}\text { Phosphorus mobilizing } \\
\text { Biofertilizers }\end{array}$} & Arbuscularmycorrhiza & $\begin{array}{l}\text { Glomus sp., Gigaspora sp., Acaulospora sp., Scutellospora } \\
\text { sp., Sclerocystissp }\end{array}$ \\
\hline & Ectomycorrhiza & Laccaria sp., Pisolithus sp., Boletus sp., Amanita sp. \\
\hline & Orchid mycorrhiza & Rhizoctoniasolani \\
\hline $\begin{array}{l}\text { Biofertilizers for Micro- } \\
\text { nutrients }\end{array}$ & Silicate and zinc solubilizers & Bacillus sp. \\
\hline $\begin{array}{l}\text { Plant Growth } \\
\text { Promoting } \\
\text { Rhizobacteria }\end{array}$ & Pseudomonas & Pseudomonas fluorescens \\
\hline
\end{tabular}

There are a vast number of research evident that biofertilizers helps in higher productivity than chemical fertilizers and some examples are likely; it was reported that biofertilizers enhanced the production as well as content of Stevioside in stevia plant when cultivated in acidic soil (Das et al., 2007; Das et al., 2009), applied vermicompost, nitroxin and cow manure mixture increases the growth characteristics of Asparagus officinalis, (Ge et al., 2016), increased plant growth and yield characters of Pisum sativum (Khan et al., 2017) etc.

\section{- Harvest management}

The harvesting of MAPs is carried out with two objectives, (i) An economic point which needs focus with type of plants that to be harvested, (ii) The Pharmacopoeial standards of which it needs to procure. Medicinal plants are needs to be harvested in optimal season and proper time period to retain the therapeutic efficacy of the plant materials. Further, the most important step is the storage of the finished herbal materials for the better desired quality. The harvesting time mainly dependent on the selection of plant part that is therapeutically effective rather than the total vegetative yield of the targeted medicinal plant parts. It is very essential to ensure that no foreign matter, weeds or toxic plants are mixed with the harvested medicinal plant materials during the harvesting of plant parts. Some examples are like some plants having maximum accumulation of phytoconstituents in particular stage and position of leaves (Digitalis, Mentha); some during particular developmental stage of leaves (Andrographis); some during specific growth period (Taxus, Uragoga), etc. Not only that, commercially, the harvesting management of MAP depends on appropriate period of harvest. It is seen that during reproductive phase, the content of active constituents are more in Catharanthus, Datura, Solanum and Dioscorea and hence, they are harvested when nearly 60-70 per cent of the reproductive phase is completed. In Costus speciosus, at the starting of reproductive phase accumulates maximum diosgenin content (Kokate et al., 2017). Some of the important parameters are like:

\section{i. Harvesting season}

Seasonal variation due to climatic condition, rainfall, heavy sun light, etc., affects the content of active constituents in plants. So, the plants are to be collected in the appropriate season to get the high medicinal value as well as more chemical constituents. Medicinal plants are harvested by avoiding dew, rain or exceptionally high humidity. If, harvesting occurs in moist conditions, the plant parts are to be transported immediately for drying to prevent any possible deleterious effects due to increased moisture levels. There is a possibility for microbial fermentation and growth of mould. Generally, roots and rhizomes are to be harvested during rainy season. Barks and flowers are harvested during autumn and gums/ resins dry weather (Das, 2018).

\section{ii. Harvesting time}

It is also an important factor that reflects the quality of the plant parts and also varied from one plant to another. When the plants are in optimum condition with their sufficient quality and efficacy, the harvesting time is to be selected at particular period. This also ensures the best possible therapeutic effectiveness of the end products because the content of biologically and medically active ingredients varies with the stage of plant growth. Roots and rhizomes should be collected when aerial parts are completely dried and harvested after Sunsets. Bark is harvested in damp weather before noon. Aerial parts should be harvested during late noon season, around 4-5 O'clock. Flowers, e.g., clove are harvested before they are fully expanded during Sunsets (Kokate et al., 2017). The oil quality in Cymbopogon martinii var. motia improved when 
harvested at 95 days or beyond (Chinnamma and Aiyer, 1988). Oil content decreased linearly with increase in intensity of shade in Ocimum gratissimum (Pillai Rekha and Chinnamma, 1994). Delayed harvest beyond flowering stage is increased linalool content in the essential oil, but decreased cineole and methyl chavicol concentrations in Ocimum basilicum (Prakasa Rao et al., 2005; Gill and Kaur, 2007).

\section{iii. Harvesting of different parts of plant}

The harvesting steps are most important to maintain the quality of the plant materials and also imparts the better therapeutic action with the phytochemicals. Different parts of the plants are collected in specific months and specific times. Many literatures revealed the therapeutic efficacy varied with the collection times which are depicted in Table 3. The fresh leaves of herb are to be picked at any time during in total growth stages. For harvesting herbal leaves for drying purposes, they should be collected in the morning after 7 am but before the heat of the Sun has warmed the plant too much. Generally, leaves should be young. Leaves from the ever green type herbs, such as rosemary and thyme, can be harvested just before flowering for the most flavour (Kokate et al., 2017). When the entire herb plant is desired, the best time to harvest, is right before the plant is about to flower. If, harvesting the whole plant from a wild growth of herbs, it is a good to harvest no more than $1 / 3$ of the plants (Das, 2018).

Table 3: Collection stages of some important MAP in India

\begin{tabular}{|l|l|l|l|l|l|}
\hline Common name & Botanical source & Part use & Collection time & Constituents & Reference \\
\hline Kalmegh & $\begin{array}{l}\text { Andrographis } \\
\text { paniculata }\end{array}$ & $\begin{array}{l}\text { Entire } \\
\text { plant }\end{array}$ & $\begin{array}{l}\text { During } \\
\text { Oct.-Nov }\end{array}$ & $\begin{array}{l}\text { Andrographolide, } \\
\text { diterpene lactone }\end{array}$ & Pandey and Mandal, 2010 \\
\hline Arjuna & Terminalia arjuna & Bark & $\begin{array}{l}\text { During } \\
\text { Feb-March }\end{array}$ & $\begin{array}{l}\text { Arjunic acid, } \\
\text { Phenolics }\end{array}$ & Pandey and Mandal, 2012 \\
\hline Indian Laurel & Litse aglutinosa & Bark & During Nov-Dec & $\begin{array}{l}\text { Tannins, mucilage, } \\
\text { phenols }\end{array}$ & Pandey and Mandal, 2012 \\
\hline Gurmar & Gymnem asylvestre & Leaves & During June and Sept & Gymnemic acid & Pandey and Yadav, 2010 \\
\hline Sweet flag & Acorusc alamus & Rhizomes & During Nov-Dec & $\begin{array}{l}\alpha \text { and } \beta \text { asarone, } \\
\text { acoric acid }\end{array}$ & Imam et al., 2013 \\
\hline Bael & Aegle marmelos & Fruit & During Feb-March & $\begin{array}{l}\text { Aegelin, rutin, } \\
\text { sitosterol, } \\
\text { marmesenin }\end{array}$ & Neeraj et al., 2017 \\
\hline Brahmi & Bacopa monnieri & Leaves & During Aug-Oct & $\begin{array}{l}\text { Bacoside, saponin } \\
\text { glycosides }\end{array}$ & Sharma et al., 2013 \\
\hline Sarpagandha & Rauvolfia serpentina & Roots & During Feb-March & $\begin{array}{l}\text { Serpentine, } \\
\text { reserpine }\end{array}$ & Mishra et al., 2009 \\
\hline Bach & Acorus calamus & Rhizome & During Sept-Oct & $\begin{array}{l}\alpha \text { and } \beta \text { asarone, } \\
\text { acoric acid }\end{array}$ & Mishra et al., 2009 \\
\hline Safed Musli & $\begin{array}{l}\text { Chlorophytum } \\
\text { borivilianum }\end{array}$ & Roots & During Sept-Dec & $\begin{array}{l}\text { Saponins } \\
\text { Mishra et al., 2009 }\end{array}$ \\
\hline
\end{tabular}

Flowers are the most delicate part of a plant to harvest. It is suitable to collect flowers during the sunny mid-day. Any damaged flowers or ant spent flowers are to be avoided to harvest. Harvested flowers are transported from the harvest container to the drying area as soon as possible to avoid bruising.

Harvesting of seeds is carried out in a dry day, just before the seed dispersion and should be hard and no longer green, brown or black in colour. Sometimes, they have a dry pod surrounded with them. It requires immense patience to not harvest too early (Kokate et al., 2017).

Plant roots are harvested in the fall, when they are full of energy. Roots are to be dug up whole. Fresh roots are cleaned properly with running tap water to remove the foreign particles and then cut while they are soft to work with. Cutting of dried roots are very difficult due to the hardness and at that time axe or any sharp instruments are required.
Plant bark is an important part of the plant so it is very essential to know the proper harvesting technique for the bark. Peeling of bark from tree in a complete ring around the trunk should not be done as it will cut off the food supply and even the tree will die. Bark is harvested during damp days to retain the moisture in bark of the young branches or young trees.

\section{iv. Harvesting temperature}

India has unique biogeographical location shaving a wide ranges of climatic conditions in ecosystems such as from coldest place, the dry cold desert of Ladakh (Nubra Valley with $-57^{\circ} \mathrm{C}$ ), to temperate, alpine and sub-tropical regions of north-west and trans-Himalayas; rain forests with high rain fall; wet evergreen humid tropics of Western Ghats and aid and semi-arid regions of peninsular India; dry desert conditions of Rajasthan and Gujarat to the mangroves of Sunderban, West Bengal. Hence medicinal plants should be harvested under the suitable climatic conditions forth specific 
species required to avoid any growth of microorganisms which minimize the deterioration of the material. It is having correlation between harvesting time and seasonal variations. During day and night time temperature variation occurs (Kokate et al., 2017). Further seasonal changes will give more variation in the temperature. It is seen that day temperature below $23^{\circ} \mathrm{C}$ is suitable for roots and bark harvest, where as, leaf, flower and fruits are to be harvested during evening time when the temperature will be $25-28^{\circ} \mathrm{C}$. The harvested leaves are dried when the air temperature is kept at 20 $40^{\circ} \mathrm{C}$, whereas for drying of other parts of plants such as roots, barks, the temperature is often raised to $60-70^{\circ} \mathrm{C}$ (Das, 2015; Das, 2018).

\section{v. Skilled persons}

For harvesting any part of the plants, a person should have basic information and enough knowledge about the plants such as botanical identification, cultivation characteristics and other environmental requirements like soil type, soil $\mathrm{pH}$, fertility, plant spacing and light requirements, harvesting techniques and storage conditions of raw materials. Therefore, all personnel including fieldworkers should maintain proper hygiene condition and should have received training regarding their hygiene responsibilities. The person should be sure about the identity of the plants he intends to harvest without doubt; he should be able to differentiate between the different species of medicinal plants in order to avoid unwanted admixtures (Kokate et al., 2017). He should select healthy and disease free plant for harvesting or else there is a chance in change of phytochemicals or may alter the ingredient profile or toxic. He should gather only plants that are abundant in that area. Special care has to be taken for delegate leaves and flowers that are very prone to deterioration than roots due to the soft nature of their anatomy. A person should harvest the plant such a way that the plant further can re-grow. Further, mechanical damage should also be avoided otherwise it can result in unwanted variation in quality. During harvesting, any foreign matter, weeds, or toxic plants are needed to be identified and discarded those plants materials to avoid mixing with the original plants materials.

\section{vi. Apparatus uses}

Special care should be taken before harvesting with the equipment. All equipments, when used, should be clean and free of remnants of before harvested plants. All the containers used during harvesting (cutting devices, harvesters, and other machines) should be clean and free from contamination and other foreign matter. If plastic containers are used, then a special care should be taken about no retention of moisture otherwise it leads to the formation of moulds. Some of the examples are roots, rhizomes, tubers harvested by diggers or lifters. Small seeds are harvested with seed stripper (Kokate et al., 2017). Thereafter, agar (sea weeds) is harvested by long handled forks. Leaves are harvested by hand plucking, barks are harvested with an axe or bush knife, etc. (Das, 2018). Some of the important parts are harvested as:

(a) Guidelines for root harvesting: Roots are important sources in several medicinal plants where number of phytochemicals are located. Therefore, the whole plant gets uprooted and never grows again. In order to ensure sustainable harvest of root material, some of the rules are like: (i) Roots are dug at a specific distance of at least $30 \mathrm{~cm}$ far surrounded by the main stem, (ii) Slicing of tap root are avoided, (iii) Only the lateral roots are collected and (iv) After digging covering the hole will ensure protection against infection and other microorganisms (Kokate et al., 2017).

(b) Guidelines for bark harvesting: Ring-barking is an unethical unsustainable practice where entire rings of bark are separated around the tree and gradually death of the tree occurs. This practices leads to any plants to become endangered. For sustainable harvest of bark material, some of the rules are: (i) The barks are peeled from the tree in small pieces leaving most of it intact on the trunk of the trees. (ii) The barks are separated from tress using flexible thin blade in the form of long vertical strips. (iii) Ring barking should be avoided. (iv) The edges of the strip should not be cut so that the remaining bark lifts from the wood. (v) After harvesting of the barks, 'treeseal' is used like, small amount of wet cow-dung is applied to the bark wound.

(c) Guidelines for leaf harvesting: In order to ensure sustainable harvesting of leaves, some rules are followed: (i) Individual leaves are plucked by hand but leaf striping, and use of sharp pruning shears are to be avoided. (ii) Regularly pruning branches will improve the quality and quantity of leaves.

(d) Guidelines for fruit harvesting: Fruits are harvested in a sustainable manner so that the biotic integrity of forests and wood lands is supported. For sustainable harvesting of fruits, some rules are followed such as: (i) All healthy, high quality fruits are not collected; those remain uncollected eventually falls on the ground so that further new plantlets should germinate. (ii) Fruits are collected from some trees and others are left completely.

(e) Harvesting of threatened species: Gradually the number of threatened species are more in world due to over exploitation. Therefore, such species should not be harvested and collected for the personal benefits or else those plants will get loss forever. A complete list on threatened plants is required to get the updated information so that harvesting of such plants will be performed by using alternative way. Furthermore, legislation should be put in place to restrict or ban to collect such plant species (Das, 2018).

\section{- Postharvest management}

Postharvest management is an inter-disciplinary "Science and Technique" for plant protection, conservation, processing, packaging, distribution, marketing, and utilization. It has potential to create rural industries. The technique imparts the quality of the food as well as efficacy of the medicinal plants. It is seen that poor post-harvest handling and a lack of knowledge on suitable packaging systems are the main reasons for wastage, poor quality and limited market opportunities. Hence, the postharvest technology is most essential and vital protocol for the maintenance of the standard quality of the medicinal plants (Das, 2018; Kokate et al., 2017).

The basic steps involves in postharvest management such as cleaning, grading, washing, drying, grinding, extraction, packaging, storage, and finally transportation. 


\section{(a) Cleaning, grading and washing}

After harvesting, raw plant materials are cleaned and then separated based on quality or size of the raw materials and then treated with the running water to remove the damaged material and soil, stones and other foreign matter.

\section{(b) Drying}

Drying is the fundamental method for postharvest preservation of medicinal plants. It allows for the conservation of the medicinal qualities of the plant material. It helps in preservation by minimizing moisture content in the product and also useful in extended shelf life. Recently, scale of production, availability of new technologies and pharmaceutical quality standards are considered for medicinal plant drying. Natural drying is generally carried out either in the field or in sheds which is used for drying of small quantities (Kokate et al., 2017). The plant constituents are generally concentrated in all plant parts (like, leaf, flower, fruit, bark or root), and therefore, harvesting and drying of parts is specific. As per the plant parts, the dryer must be selected for drying. For seed drugs, such as fennel or caraway, typical grain dryer types are used. Drying of medicinal plant material directly on open field without any material on ground is avoided. On a concrete or cement surface, tarpaulin or other appropriate cloth or sheeting is used for drying of the plant materials. Special observation should give to keep away the birds, insects, rodents, etc., to avoid disturbance during drying. For indoor drying, the duration of drying, drying temperature, humidity and other conditions are to be selected based on the plant parts. It is also advisable that volatile oil content leafy plant materials are dried in shade to retain the quality of volatile constituents.

\section{- Factor affecting drying}

\section{i. Temperature}

The temperature plays an immense role on the quality of the medicinal plant materials. Therefore, drying temperature is selected as high as possible without hampering the quality of the product. If, the plant requires enzymatic action, then slow drying at moderate temperature is necessary. For example, drying of vanilla pods, cocoa seeds and Gentian root, enzymatic action is required. The colour and odour of vanilla are only developed during fermentation by the enzyme action. Fermentation helps to remove bitter or unpleasanttasting substances an even for the formation of sweet smell of the aromatic compounds. During this curing process, the pods undergo fermentation and turn black in color. It is seen that after collection, the drying is takes place as soon as possible without any enzymatic action like Digitalis leaves. Content of absolute vapour in the drying air is controlled by adjustment of the dew-point temperature that is ranges from 30 to $90^{\circ} \mathrm{C}$. The air temperature of $20-40^{\circ} \mathrm{C}$ for thin materials such as leaves is suitable for drying but often increased to $60-70^{\circ} \mathrm{C}$ for harder plant like barks and roots. By increasing temperature, drying time decreases exponentially. Therefore, the minimisation of drying time with an increasing air temperature is always preferable, because capacity of a dryer will be increased and allow for desired reduction of drying costs. In similar experiments with flowers of Chamomilla recutita, drying time is reduced from $52 \mathrm{~h}$ at $30^{\circ} \mathrm{C}$ to $1.6 \mathrm{~h}$ at $60^{\circ} \mathrm{C}$ (Muller et al., 1996). For roots of Echinacea angustifolia, the relation is $56 \mathrm{~h}$ at $30^{\circ} \mathrm{C}$ to $6.5 \mathrm{~h}$ at $60^{\circ} \mathrm{C}$, for Salvia officinalis, drying time is reduced from 120 $\mathrm{h}$ at $30^{\circ} \mathrm{C}$ to $2 \mathrm{~h}$ at $50^{\circ} \mathrm{C}$ because the colour degradation is observed when the drying air temperature increases from 50 to $55^{\circ} \mathrm{C}$ (Muller et al., 2007). Maximum temperature of $100^{\circ} \mathrm{C}$ is recommended for glycosidal drugs, for mucilage species $65^{\circ} \mathrm{C}$ whereas for essentialoil species 35 to $45^{\circ} \mathrm{C}$. The contents of chavicol and eugenol in Ocimum basilicum decreased during drying at $45^{\circ} \mathrm{C}$, but transbergamotene, linalool and 1,8-cineole content increased (Rocha et al., 1993). Several literatures revealed the chemical composition of essential oil of medicinal plants significantly varied with the drying air temperature (Baydar and Erbas, 2009; Sellami et al., 2011).

\section{ii. Relative humidity (RH)}

Normally RH above $70 \%$ shows the growth of micro-organisms, like fungi, yeasts and bacteria. Even, at high moisture environment, the activity of decomposing enzymes is also enhances, therefore, a threshold of RH $60 \%$ is recommended for the storage of medicinal plants to retain their quality. Hence, drying is essential in mitigation of high risk of growth of microbes. Plant parts such as leaves contain $60-90$ per cent, roots and rhizomes contain $70-85$ per cent, and wood contains 40-50 per cent of water whereas the lowest percentage of water (Not more than 5-10\%) content revealed in seeds (Kokate $e t$ al., 2017). Hence, drying helps in moisture content in plants. It is seen that $\mathrm{RH}$ in a range from 30 to 70 per cent is optimum for wide ranges of medicinal plants (Das, 2018).

\section{iii. Velocity}

The higher essential oil content (linalool) in Ocimum basilicum was reported with the air velocity of $1.9 \mathrm{~m} / \mathrm{sin}$ and the air temperature at $60^{\circ} \mathrm{C}$ (Soaes et al., 2007), whereas content of phytochemicals in lemon grass leaves showed non-significant result at air velocities of $0.5 \mathrm{~m} \mathrm{~s}^{-1}$ and $1.0 \mathrm{~m} \mathrm{~s}^{-1}$ (Martins et al., 2007).

\section{- Drying method}

Drying method is depending on the type of chemical constituents present in the plant parts (Figure 3) because on proper drying condition, the chemical changes of the medicinal plants are varied (Costa et al., 2005; Fennell et al., 2004). There are two main drying methods of medicinal plants such as natural and artificial drying methods (Ahmed et al., 2013; Kokate et al., 2017; Das 2018).

\section{(i) Natural drying}

Drying method is carried out by natural air in Sun or shade. Henceforth, the nature of drying for the plant constituents is dependent on the nature of the sensitivity to light. The plant materials are spreaded out in thin layers on drying frames for the open air natural drying. For proper drying with adequate air circulation, the drying frames are to be kept in a sufficient height above the ground so that uniform drying helps to resist microbial attack and mould formation. Thermostable plant constituents containing plants are to be dried directly in sun like gum, acacia, seeds and fruits, etc. To maintain the colour of leaves (Digitalis, Senna) and flowers (Clove); shade drying is preferred. Thereafter, volatile oil containing plant materials are dried at lower temperatures in shade like mints, peppermint, Patchouli, Eucalyptus, etc. (Kokate et al., 2017). The drying conditions are needed to be recorded. Herbs such as mint and basil are needs to be rapid drying to avoid mould attack because they contain high moistures in their leaves. To retain the green colour of the plant canopies and to get the more volatile oil, they are dried in the dark by hanging upside down in bunches in 
paper bags. It revealed that the oil content of shade-dried Roman chamomile flowers contains larger $(1.9$ per cent w/w) than that of sun $(0.4$ per cent $)$ and oven-dried at $40^{\circ} \mathrm{C}(0.9$ per cent) (Das, 2018). General leaves are dried by tying whole stems very tightly in small bunches, then hanged in a dark, warm $\left(21.1^{\circ} \mathrm{C}-26.7^{\circ} \mathrm{C}\right)$, well-ventilated, dust-free area. When herbs are not adversely affected by excessive sunlight, the air drying is recommended but when sunlight causes discoloration and warping/shrivelling of the plant constituents, the shade drying is recommended.

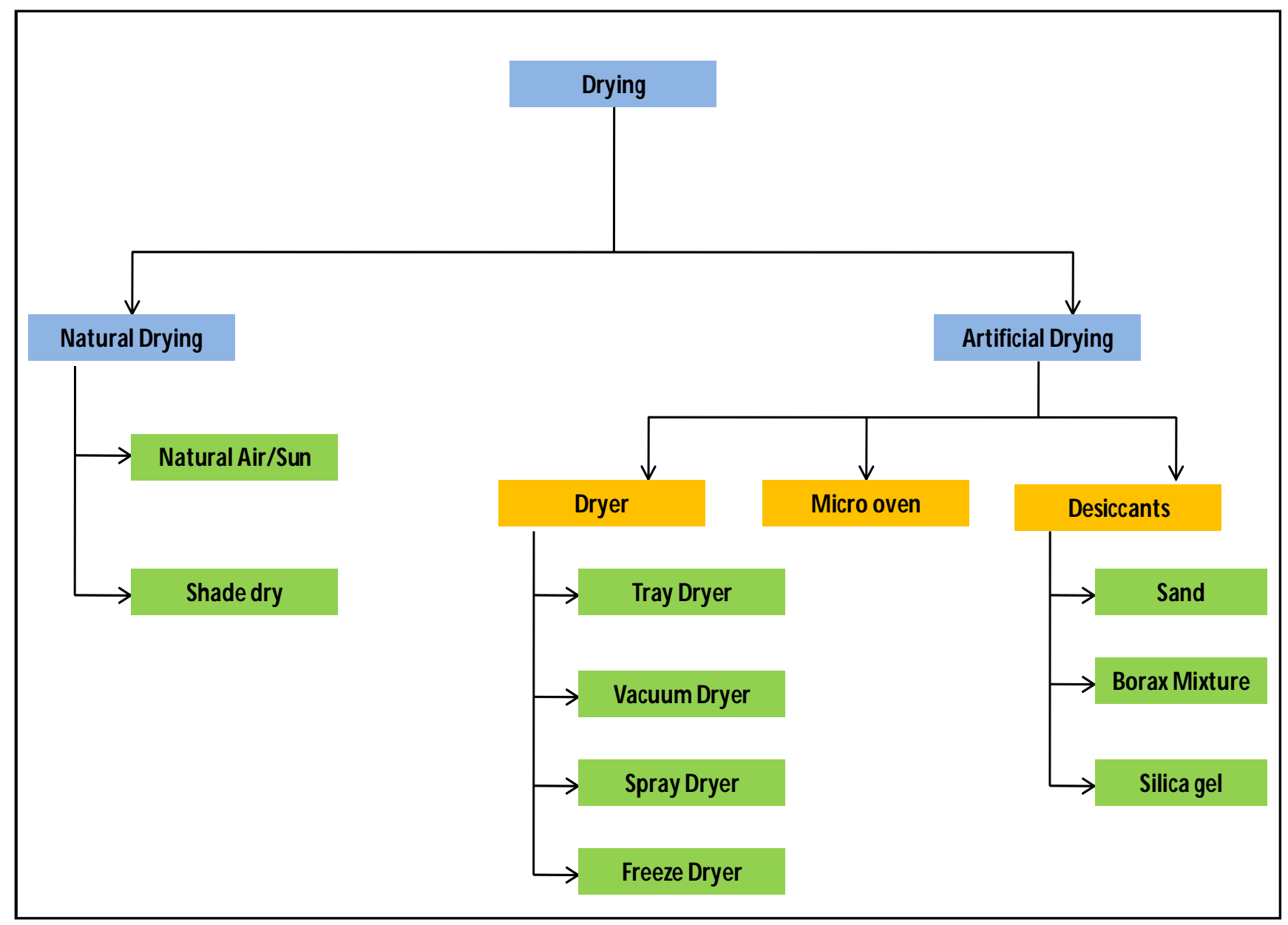

Figure 3: Various drying methods.

\section{Disadvantages of natural drying}

(a) Sometimes plants are placed by hand on drying frames or stands, to be air-dried in sheds.

(b) It is labor-intensive and takes longer period to dry.

(c) The method is dependent on temperature and humidity for the complete proper drying.

\section{Artificial drying}

This is very fast method performed at maintained fixed temperature that is carried out by direct fire, heated stones, hot water pipes, by use of stoves, drying chambers with controlled temperature and ventilation, etc. Various methods like tray drying, vacuum drying, spray drying, Freeze drying, Microwave drying, etc., are used.

\section{Advantages}

(a) Generally the most acceptable form of drying herbs. (b) It is a rapid (minimal exposure to heat with minimum chances of chemical alteration) method which reduced the drying time to hours or minutes.

(c) In this technique, temperature is controlled (about $40^{\circ} \mathrm{C}$ maintained) and ventilation for dry air to replace wet air.

(d) Labor can also be greatly reduced.

Desiccants (Batukray, 2019)

Sand: Sand is used as desiccant. Sand is least expensive and oldest method but still one of the best desiccants. It is dry, fine and almost salt free. 2:1 ratio borax and sand with 1 tablespoon of salt mixture is for accelerate drying method.

Borax mixtures: Pure borax is used for rapid drying but having disadvantage of burning and/or bleaching the delicate flowers. Borax mixed with white or yellow corn meal is sometimes used for the slow drying process. 
Saltor silica gel: Commonly silica gel is used for drying of flowers to retain the original colour and also it acts as the fast acting drying agent. The silica gel beads are blue crystal and also hygroscopic in nature so by absorbing water or moisture it forms pink colour. It is an expensive but effective desiccant for longer usage for drying the plant materials.

\section{Comminution}

The active principle of the plants are provides the medicinal qualities or therapeutic efficacy. Hence, the active principles are required to separate from the plant constituents by means of extraction. The solubility of the constituents in the respective solvent is the basic theory of the extraction method. The phytoconstituents contained in every medicinal plant consist of a number of compounds, which individually or in groups can have a specific action on the human body. Different methods are used to extract these phytoconstituents in a crude extract form in which active principles are present, either sole or collectively. Hydroalcoholic solvent mixture is having the greatest extractive power for extraction of phytochemicals such as alkaloids, saponins and flavonoids from wide ranges of the plant species (Zhang et al., 2018). Ethanol uses for getting various tinctures, fluid, soft and dry extracts. Several types of machines are available for grinding crude drugs which increases the surface tension and reduce the size reduction that further helps in easy extraction. Some mills are used for size reduction of plant drugs, namely;

- Hammer mill: A common type for grinding crude drugs like drugs containing hard bark.

- Knife mill: The mill is applied for the procurement of lowdust powders of leaves, barks and roots.

- Tooth mill: The mill is used to get very fine powders for the herbals. For heat sensitive compounds, the mills are cooled with liquid nitrogen. Generally for volatile oil containing crude drugs are size reduced by cold grinding technique.

- Sieving: The plant material is passed through numerous sizes of according to the requirements. The two fractions are getting separated in which components with smaller particle size passes through the sieve and remaining coarse particles are getting separated on top of the sieve which is further send back to the mill for grinding.

- Blast sifting: In this method, the drugs are processed for dust removal activity using blown with compressed air and also it allows the precipitation of the particles based on the weight.

\section{Extraction}

Various extraction procedures are available like infusion, maceration, percolation, digestion, decoction, continuous hot extraction, solvent-solvent precipitation, liquid- liquid extraction, distillation, modern modified procedures like microwave extraction, super critical fluid extraction, bioassay graded fractionation, etc., for medicinal and aromatic plant extraction.

- Infusion: This method is used for preparation of herbal tea. The plant material is placed in a pot and wetted with cold water. Furthermore, boiling water is poured and left to stand with covered lid for several times.
- Maceration: This extraction process is used for water-soluble active constituents with the cold water at $15-20^{\circ} \mathrm{C}$ for several hours.

- Percolation: A special type of percolator is used for the extraction of the powdered plant material with the sustained flow of the solvent.

- Digestion: The method is conventional type where long extraction method is used for extraction of hard barks or woods. Generally, the method is carried out using maceration method which is carried out at elevated temperature in the range of $35-40^{\circ} \mathrm{C}$.

- Decoction: The method is used conventionally where the plant material is boiled with water and is kept for several minutes. Generally, at the ratio of 1:4 or 1:16 of crude extract to water is used for the extraction. Finally, the volume of extract is then brought down to one-fourth by boiling the liquid extract. Then the concentrated extract is used for further process.

- Continuous hot extraction method: This extraction method is used for the extraction of organic constituents present in dried plant. The most common method is Soxhlet method which is used in both laboratory and industries based on the batch size and batch volume and the extraction is carried out based on the increasing polarity of the solvent, i.e., non polar to polar solvents.

- Solvent-solvent precipitation: (i) In this method, less polar but miscible solvent is used to dissolve the plant extract which causes the selective precipitation of the less soluble plant constituent. Likewise, by addition of acetone in the methanol extract of Phytolacca dodecandra, triterpenoid saponins are precipitated. Similarly, by adding alcohol in aqueous extracts of Olibanum, the gum is precipitated. (ii) By adding an extract into the solvent where the phytoconstituents are sparingly soluble or completely insoluble such as by adding acidic water or distilled water into alcoholic extract, resulted the precipitation of resins.

- Liquid-liquid extraction: The method of extraction is also known as partitioning or solvent extraction method where two different immiscible liquids are used to separate compounds based on their relative solubility. It is performed generally by using a separating funnel where two liquid phases are clearly separated.

- Counter current extraction: This is a highly effective process whereby solvent flows in the opposite direction to plant material. Unlike maceration and percolation, which are batch processes, this method is continuous. Screw extractors and carousel extractors are two types of equipment used for counter current extraction.

- Extraction with supercritical gases: The active ingredients from plant materials are extracted by means of gases. It is a very efficient technology for extraction that working at low temperature and hence temperature-sensitive components is extracted without any trouble. The extractor contains a vessel where powdered plant material is placed and gas is supplied 
under controlled temperature and high pressure. The gas dissolves the active ingredients inside the cells of plant material and then passes into a separating chamber where both pressure and temperature are lower. The extract precipitates out very fast without any residual solvent in the chamber. The used gas is possible to further reuse. Such some important gases those used in supercritical extraction as solvents are carbon dioxide, nitrogen, methane, ethane, ethylene, nitrous oxide, sulfur dioxide, propane, propylene, and ammonia, etc.

- Steam distillation: The method is conventional type for extraction of active ingredients from plants sources by applied direct steam to the cylindrical tank where the powdered plant material is loaded. The steam is directly imbibe the plant materials and the constituents are comes out faster through the cell ruptured and then enters a condenser where it is condensed back into a liquid. This condensate again passes into a flask and the process is continues until no more extract present in the condensate. The same water is mainly reused and finally the extract is purified using centrifugation followed by filtration.

- Phytonics process: The phytonics is mainly useful extraction process for high quality natural essential oils, and flavours that are directly used without further any treatments (physical or chemical). This process involves the use of a novel non-toxic solvent based on hydrofluorocarbon-134a, having a boiling point of $-25^{\circ} \mathrm{C}$ with a vapor pressure of 5.6 bar at normal room temperature. It is very efficient technique for the extraction of plant materials.

\section{Storage}

After completion of drying process, plants are packaged for transportation and further usage. Dried herbaceous plants are compressed into bales weighing from 60 to $100 \mathrm{~kg}$, which are then sewn into fabric bags or wrapped in plastic. Materials that cannot be baled, such as roots and bark, are placed in sacks. Smaller bags may be used for dense materials such as dried fruits or seeds. Very fragile materials, such as flowers, are packaged incrates. Dried plant materials tend to be hygroscopic (readily absorbing moisture) and must be stored under controlled humidity. Highly hygroscopic materials are generally packed in plastic (Anbarasan et al., 2018). The crude drugs like roots, barks, large barks are packed in gunny bags. Storage is the main process to maintain the quality of the crude drugs and to protect the drugs from the insect attack (Thakur et al., 2011). Moisture resistant sealed containers are used to storage of dried leaves to prevent microbial contamination, such as canning jars with sealed lids. Seeds are stored in whole form in glass or sealed plastic containers and grinded before usage. Whole shade dried leaves retain their oil and flavour than sun dried and grinded form and crushed before experimentation. Dried drugs are protected from moisture during storage. Table 4 shows various storage conditions for various drugs. Some factors that affect storage of crude drugs as well as harvested plant materials are like,

Table 4: Storage condition of crude drugs

\begin{tabular}{|l|l|}
\hline Name of the medicinal plants & Packing method \\
\hline Aloe & Goatskin \\
\hline Colophony and Balsam of tolu & Kerosene tin \\
\hline Asafoetida & Wellclosed container to prevent loss of volatile oil \\
\hline Codliveroil & Brown colored bottle to prevent light \\
\hline Digitalis & Well closed container with desiccating agents to absorb excessive moisture from the drug \\
\hline Opiumseeds & Plastic sealed cover \\
\hline
\end{tabular}

\section{Condition for storage materials}

Plant materials should be store in well aerated, dry and protected from light. Raw materials are supplied in humidity controlled materials in air-conditioning conditions. This will help to prevent insects and rodents attacks and also the materials will be fresh for the further use whenever required (Pandey and Savita, 2017).

\section{Condition for store house}

The floor should be tidy, without cracks and easy to clean. Plant materials are stored on shelves which keep the material a sufficient distance from the walls. Safety measures are taken to prevent the occurrence of pest infestation, mould formation, rotting or loss of oil. Regular inspections are carried out at regular intervals.

\section{Packaging}

Substandard materials, contaminants and foreign matter are eliminated as per the standard in-process quality control procedures during the end stage of packing. In compliance with standard operating procedures and National or regional regulations of the producer and end user countries, processed medicinal plants are packed in clean, dry boxes, bags or any good containers (WHO, 2003). Packaging materials are to be selected based on cleanliness, non-polluted, dry and in good condition. The fragile medicinal plant materials are packaged in rigid containers. Fresh plant materials are stored at $2-8^{\circ} \mathrm{C}$ whereas frozen products are stored at $-20^{\circ} \mathrm{C}$ and for crude drug storage, wooden boxes and paper bags are to be avoided (Anonymous, 2009).

\section{Conclusion}

The total quality management through Good Agricultural Practices for medicinal and aromatic plants is very challengeable and laborious task. The most importantly, therapeutic efficacy of the plant parts greatly dependent on pre and post-harvesting technologies, processing and storage systems. These activities are integral 
parameters in conservation as well as in biodiversity resource management. The total process is a part of the quality control for standardization of the MAPs that focused on the consistency in safety, efficacy and quality of the raw herbals and their extracts. Furthermore, supply of the healthy raw materials throughout the year through proper marketing, provides sound economic benefits, employment and many other opportunities.

\section{Acknowledgements}

Authors are thankful to the Principal, Sri Adichunchanagiri College of Pharmacy, B.G.Nagar for provided all facilities for completing the review.

\section{Conflict of interest}

The authors declare that there are no conflicts of interest relevant to this article.

\section{References}

Ahmed, N.; Singh, J.;Chauhan, H.;Anjum, P.G.A. and Kour, H. (2013). differen drying methods: Their applications and recent advances. International Journal of Food Nutrition and Safety, 4(1):34-42.

Anbarasan, A.;Nataraj, J.;Shanmukhan, N. and Radhakrishnan, A. (2018). Effect of hygroscopicity on pharmaceutical ingredients, Methods to determine and overcome: An overview. Journal of Chemical and Pharmaceutical Research, 10(3):61-67.

Anonymous. (2009). Guidelines on good field collection practices for Indian medicinal plants. National Medicinal Plants Board, Department of AYUSH, Ministry of Health and Family Welfare Govt. of India, New Delhi.

Batukray, J.D. (2019). Progressive review on use of desiccant drying in agricultural applications. Journal of Agricultural Science and Engineering, 5(1):24-31

Barman, M.; Paul, S.;Choudhury, A.G.; Roy, P. and Sen, J. (2017). Biofertilizer as prospective input for sustainable agriculture in India. Int. J. Curr. Microbiol. App. Sci., 6(11):1177-1186.

Baydar, H. and Erba, S. (2009). Effects of harvest time and drying on essential oil properties in lavandin (lavandula $\times$ intermediae mericex loisel.). Acta Horticulturae, 826: 377-382.

Bodeker, C.;Bodeker, G.;Ong, C.K.; Grundy, C.K.;Burford, G. and Shein, K. (2005).WHO Global Atlas of Traditional, Complementary and Alternative Medicine. Geneva, Switzerland: World Health Organization.

Chandler, D.; Bailey, A.; Tatchell, G.M.; Davisdon, G. and Greaves, J. (2011).The development, regulation and use of biopesticides for integrated pest management. Phil. Trans. R. Soc. B., 366:1987-1998.

Chatterjee, S.K. (2002). Cultivation of medicinal and aromatic plants in India: A commercial approach. In: Proc. Int. Conf. on MAP; Acta Hort., 576:191-202.

Chin Quek, R.Y.; Yi Peh, E.W. and Henry, C.J. (2020). Effects of Cocoa Butter and Cocoa Butter Equivalent in a Chocolate Confectionery on Human Blood Triglycerides, Glucose and Insulin. Foods, 9(455); 1-10. doi: $10.3390 /$ foods 9040455

Chinnamma, N.P. and Aiyer, R.S. (1988). Effect of fertilizers and harvests on palmarosa oil quality. Indian Perfumer., 32(3):220-224.

Costa, L.C.B.;Corrêa, R.M.; Cardoso, J.C.W.; Pinto, J.E.B.P.;Bertolucci, S.K.V. and Ferri, P.H. (2005). secagem e fragmentação da matériaseca no rendimento e composição do óleoessencial de capim-limão. HorticulturaBrasileira., 23:956-959.
Dara, S.K. (2016). IPM solutions for insect pests in California strawberries: Efficacy of botanical, chemical, mechanical, and microbial options. CAPCA Adviser.,19(2):40-46.

Das, D.K. (2015). Introductory Soil Science. Kalyani Publishers, Ludhiana, Punjab.

Das, K. (2018). Pharmacognosy and Phytochemistry-I. Nirali Prakashan, ISBN No: 938870636-6.

Das, K. (2020). Herbal Drug Technology. Nirali Prakashan, ISBN No: 938994430-9.

Das, K.; Dang, R.;Shivananda, T.N. and Sekeroglu, N. (2007). Influence of biofertilizers on the biomass yield and nutrient content in Stevia (Stevia rebaudiana. Bert) grown in Indian subtropics. Journal of Medicinal Plants Research, 1(1):5-8.

Das, K.; Dang, R. and Shivananda, T.N. (2009). Effect of biofertilizers on the nutrient availability in soil in relation to growth, yield and yield attributes of Stevia rebaudiana Bert. Archives of Agronomy and Soil Science., 55(04):359-366.

Easton, Z.M. (2016). Soil and Soil Water Relationships. Virginia Cooperative extension.1-9. https://ext.vt.edu/content/dam/ ext_vt_edu/topics/agriculture/water/documents/Soil-and-SoilWater-Relationships.pdf.

Fennell, C.W.; Light, M.E.;Sparg, S.G.; Stafford, G.I. and Staden, J.V. (2004). Assessing African medicinal plants for efficacy and safety: Agricultural and storage practices. Journal of Ethnopharmacology, 95:113-121.

Foster, S. (1993). Medicinal plant conservation and genetic resources. Acta. Horticulture, 330:6-74.

Gareau, S.E. (2004). Analysis of plant nutrient management strategies: Conventional and alternative approaches. Agriculture and Human Values, 21:347-353.

Ge, C.;Radnezhad, A.;Abari, M.F.;Sadeghi, M. and Kashi, G. (2016). Effect of biofertilizers and plant growth promoting bacteria on the growth characteristics of the herb Asparagus officinalis. Applied Ecology and Environmental Research, 14(3):547-558.

Gill, B.S. and Kaur, S. (2007). Cultivation of Ocimum basilicum L. and chemical composition of its herb oil. Indian Journal of Arecanut, Spices and Medicinal Plants, 9(2):70-73.

Gougoulias, C.; Clark, J.M. and Shaw, L.J. (2014).The role of soil microbes in the global carbon cycle: Tracking the below-ground microbial processing of plant-derived carbon for manipulating carbon dynamics in agricultural systems. J. Sci. Food Agric., 94(12):23622371 .

Guo, H.; White, J.;Zhenyu, W. and Xing, B. (2018). Nano-enabled fertilizers to control the release and use efficiency of nutrients. Current Opinion in Environmental Science and Health, 6:10.1016/ j.coesh.2018.07.009.

Haile, F. (2017). Comparison of factors on the total pyrethrin content extraction from pyrethrum flower (Chrysanthemum cinerariae folium). International Journal of Advanced Research, 5:509-514. $10.21474 /$ IJAR01/5554.

Hamilton, A.C. (2008). Medicinal plants in conservation and development: Case studies and lessons learned. In: Kala CP, editor. Medicinal plants in conservation and development. Salisbury: Plantlife International Publisher, pp:1-43.

Imam, H.;Riaz, Z.;Azhar, M.;Sofi, G. and Hussain, A. (2013). Sweet flag (Acorus calamus Linn.): An incredible medicinal herb. International Journal of Green Pharmacy, 7:288-296.

Khader Khan, H. (1996). Integrated pest management and sustainable agriculture. Farmers and Parliament, 30(2):15-17. 
Khan, I.; Singh, D. and Jat, B.L. (2017).Effects of biofertilizers on plant growth and yield characters of Pisum sativum L. Adv. Res. J. Crop Improv., 8(1):99-108.

Kokate, C.K.;Purohit, A.P. and Gokhale, S,B. (2017). Pharmacognosy 54th Edition. Nirali Prakashan, Pune.

Liu, Z.J. and Cordes, J.F. (2004). DNA marker technologies and their applications in aquaculture genetics. Aquaculture, 238:1-37.

Mannan, A.R.;Kanan, G.G.;Niraj, Y.V. and Nishit, D.P. (2020). Estimation of withaferin., from Ashwagandha dilehya using HPLC. 11(1):334-342.

Martins, P.M.;Melo, E.C.; Almeida, L.C.B.; Santos, R.H.S. and Machado, M.C (2007). Influência da temperature velocidade do ar de secagem no teor e nacomposiçãoquímica do óleoessencial de campim-limão (CymbopogoncitratusStapf). Acta. Horticulture, 569:14-21.

Mishra, M.;Kotwal, P.C. and Prasad, C. (2009). Harvesting of medicinal plant in the forest of central India and its impact on quality of raw materials: A case of Nagpur district, India. Eco. Print, 16:35-42.

Mortensen, L. (2000). Effects of air humidity on growth, flowering, keeping quality and water relations of four short-day greenhouse species. Scientia Horticulturae, 86(4):299-310.

Mousavi Maleki, S.A.;Hizam, H. and Gomes, C. (2017). Estimation of Hourly, Daily and Monthly Global Solar Radiation on Inclined Surfaces: Models Re-Visited. Energies, 10:1-28.134;doi:10.3390/en 10010134

Müller, J. (2007). Convective drying of medicinal, aromatic and spice plants: A review. Stewart Postharvest Review, 4:2. doi: 10.2212/ spr.2007.4.2.

Müller, J.;Köll-Weber, M.; Kraus, W. and Mühlbauer, W. (1996). Trocknungs verhalten von Kamille (Chamomillarecutita (L.) Rauschert). ZeitschriftfuerArzneiundGewuerzpflanzen., 1(3):104-110.

Naik, K.; Mishra, S.;Srichandan, H.; Singh, P.K. and Choudhary, A. (2020) Microbial formulation and growth of cereals, pulses, oilseeds and vegetable crops. Sustain. Environ. Res., 30: 10. https://doi.org/ $10.1186 / \mathrm{s} 42834-020-00051-\mathrm{x}$

Neeraj, Bisht V. and Johar, V. (2017). Bael (Aegle marmelos) extraordinary species of India: A review Int. J. Curr. Microbiol. App. Sci., 6(3): 1870-1887.

Neina, D. (2019).The Role of Soil pH in Plant Nutrition and Soil Remediation. Applied and Environmental Soil Science., pp: 1-9. https://doi.org/10.1155/2019/5794869.

Niiho, Y.; Yamazaki, T.; Nakajima, Y.; Yamamoto, T.; Ando, H.; Hirai, Y.; Toriizuka, K. and Ida, Y. (2006). Gastroprotective effects of bitter principles isolated from Gentian root and Swertia herb on experimentally-induced gastric lesions in rats. Journal of Natural Medicines, 60:82-88.10.1007/s1 1418-005-0014-2

Pandey, A.K. and Yadav, S. (2010). Variation in gymnemic acid content and non-destructive harvesting of Gymnema sylvestre (Gudmar). Phcog. Res., 2(5):309-342.

Pandey, A.K. and Mandal, A. K. (2010). Variation in morphological characteristics and andrographolide content in Andrographis paniculata (Burm.f.) Nees of central India, Ira. J. En. and Env., 1(2): 165-169.

Pandey, A.K. and Mandal, A.K. (2012). Sustainable harvesting of Terminalia arjuna(Roxb.) Wight \&Arnot (Arjuna) and Litseaglutinosa (Lour.) Robinson (Maida) bark in central India. J. Sus. For., 31(3):294-309.
Pandey, A.K. and Das, R. (2014). Good Field Collection Practices and Quality Evaluation of Medicinal Plants: Prospective Approach to Augment Utilization and Economic Benefits. Res. J. Med. Pl., 8:1-19.

Pandey, A.K. and Savita. (2017). Harvesting and post-harvest processing of medicinal plants: Problems and prospects. The Pharma Innovation Journal, 6(12):229-235.

Pillai Rekha, R. and Chinnamma, N.P. (1994). Studies on the herbage yield and eugenol content of Clocimum oil (Ocimum gratissimum Linn.) grown under varying levels of shade. South Indian Horticulture, 42(1):63-65.

Prakasa Rao, E.V.S.;Ganesha Rao, R.S. and Ramesh, S. (1996). Changes in content and composition of some essential oils due to possible deficiencies of phosphorus and potassium in a red soil region of Bangalore. Pafai Journal, pp:25-27.

Prakasa Rao, E.V.S.;GaneshaRao, R.S.;Puttanna, K. and Ramesh, S. (2005). Significance of harvest intervals on oil content and citral accumulation in lemongrass (Cymbopogon flexuosusvar. Krishna). Journal of Medicinal and Aromatic Plant Sciences, 27:1-3.

Prakasa Rao, E.V.S.; Puttanna, K.; Ganesha Rao, R.S. and Ramesh, S. (2007). Nitrogen and potassium nutrition of French basil (Ocimum basilicum Linn.). Journal of Spices and Aromatic Crops, 16(2):99-105.

Rocha, T.;Lebert, A. and Marty-Audouin, C. (1993). Effect of pretreatments and drying conditions on drying rate and colour retention of basil (Ocimum basilicum). Lebensmittel-Wissenschaft und Technologie, 26(5):456-463.

Smitha, G.R. (2019). Influence of Pre and Post-Harvest Factors on Yield and Quality of Medicinal and Aromatic Plants. Medicinal and Aromatic Crops Conservation and Cultivation, Publisher: Akinik Publications, New Delhi, Chapter-11. pp: 116-143.

Sneha, S.;Anitha, B.; Anjum Sahair, R.; Raghu, N.; Gopenath, T.S.; Chandrashekrappa, G.K. and Kanthesh, M.B. (2018). Biofertilizer for crop production and soil fertility. Academia Journal of Agricultural Research, 6(8):299-306.

Sellami, I.H.; Wannes, W.A.; Bettaieb, I.; Berrima, S.; Chahed, T.; Marzouk, B. and Limam, F. (2011). Qualitative and quantitative changes in the essential oil of Laurus nobilis L. leaves as affected by different drying methods. Food Chem., 126:691-697.

Sharma, M.;Khajuria, R.K. and Sharada, M. (2013). Annual variation in bacoside content of Bacopa monnieri (1.) Wettst plants. Int.J. Pharm. Bio. Sci., 4(4): 266 - 271.

Soares, R.D.; Chaves, M.A.; Silva, A.A.L.; Silva, M.V. and Souza, B.S. (2007). Influência da temperatura e velocidade do arnasecagem de manjericão (Ocimum basilicum L.) com relaçãoaosteores de óleosessenciais e de linalol. Ciência e Agrotecnologia.,31:11081113.

Thakur, L.; Ghodasra, U.; Patel, N. and Dabhi, M. (2011). Novel approaches for stability improvement in natural medicines. Pharmacogn Rev., 5(9):48-54. doi:10.4103/0973-7847.79099

World Health Organization. (WHO) (2003). Guidelines on Good Agricultural and Collection Practices (GACP) for Medicinal Plants. World Health Organization, Geneva.

Zhang, Q.W.; Lin, L.G. and Ye, W.C. (2018). Techniques for extraction and isolation of natural products: A comprehensive review. Chin Med., 13:20.https://doi.org/10.1186/s13020-018-0177-x. 